\title{
Influence of teaching and learning aids on language learning in four selected schools of Mwense District in Luapula Province, Zambia
}

\section{Lufeyo Chitondo}

Rockview University, Lusaka, Zambia

DOI - http://doi.org/10.37502/IJSMR.2022.5110

\begin{abstract}
This study was an attempt to investigate the influence of teaching and learning aids on language teaching as a foreign language in Mwense district of Zambia. The study sampled participants using purposive and simple random sampling methods to come up with a sample size of 121respondents. Interview guides were used to obtain qualitative data which was analysed using thematic analysis while quantitative data were collected using questionnaires which were analysed using descriptive statistics. The study employed a descriptive survey research design. The study revealed that the use of teaching aids is important because they help learners gain understanding through multiple impressions recoded through the eye, ear, touch and other series; they help a teacher overcome his physical difficulties of presenting subject matter, they encourage participation and they enhance communication skill while actively engaged in solving meaningful problems. Further the study revealed that teaching aids stimulate interest and serve as source of information, and make learning permanent. They attract and sustain attention, develop interest of learners, adjust learning climate and promote acceptance of an idea. Overly, the study revealed that teaching aids have influence on language learning process, teachers rarely used teaching aids even though these aids were there in school, teachers noted that lessons accompanied by teaching aids were more satisfying than those without and that time spent on a lesson accompanied with teaching aids was worthwhile and not equal to that which did not use teaching aids.
\end{abstract}

Keywords: Artifacts, audio-visual aids, axial coding, choral recitals, pedagogy.

\section{Introduction}

English language is the official language in Zambia after being a British protectorate and (Mwanakatwe, 2013) notes that from the time of colonialism to date emphasis on English as a medium of instruction has not changed. (Baruah, 2006) notes that language skills, like any other skill can be acquired only through practice. In the mother-tongue (LI) language the child gets sufficient scope for this practice in his or her environment. She/he uses the language at home, in the playgrounds, at dance parties, at school and everywhere. The practice for the mother tongue language is made more perfect because everyone around speaks it. 
The teaching of language is mostly suited to a particular situation or context. It is said that a full meaning of a language unit is known only when this situation is known. (Fries, 1976) notes that the only true and correct meanings of words are the situations in which they are used. A word consists of a sound or contribution of sound that has become conventionalized in a high in a culture or a linguistic community, that is used in certain situations and that stimulates certain responses in the hearer belonging to the same community.

Furthermore, some teachers who teach English as a foreign language insist on the theory that emphasizes that knowledge of structures must be linked to situations in which they could be used. This emphasis gave a distinctive feature to Situational Language Teaching. British linguistics like Halliday and Firth developed powerful views of language in which meaning, context and situation were given a prominent place. This now leads us to the emphasis on the description of language activity as part of the whole complex of events which, together with the participants and relevant objects, make up actual situations (Halliday, McIntosh and Strevens 1964: 38). According to Richards and Rodgers (1985) the theory that explains the impact of environment and culture on language development is the behaviourist theory. Thus the theory of learning that underlies Situational Language Teaching is a type of the behaviourist habit-learning theory. Language is acquired in the same way as any other behaviour, through operant conditioning. In operant conditioning, learning is defined as changes in behaviour as a result of experiences that occur after a response. Operant conditioning occurs in language development when sounds are made by a child and then reinforced by its parents' reactions. For example reinforcement would come through an excited smile, hugs and attention whenever a sound makes a resembling a word is made. This makes the child more likely to repeat the word and associate it with a corresponding object or event. Process is thus more important than conditions of learning. As Palmer pointed out, there are three processes in learning a language: receiving the knowledge or materials, fixing it in the memory by repetition and using in actual practice until it becomes a personal skill. (1997:136).

As much as possible this context, situational thinking leads us to Social Interactionist Theory which is an approach to language acquisition that stresses the environment and the context in which the language is being learned. It focuses on practice (pragmatics) of language rather than grammar which should come later.

In this approach, the beginning speaker and the experienced speaker whether a child and adult or second language learner and fluent speaker exist in a negotiated arrangement where feedback is always possible. The basic principle for this theory as already noted is the importance of the home and the cultural environment in early childhood language acquisition. Language is not innate ability as (Chomsky, 1964) would say. I t develops in a negotiated environment.

This theory makes sense largely if the teacher is aware of the context. Thought does not make objects; it reflects them on the context in which they are found. For example: mango, laughing, table, etc. These words are already in the environment. If the child makes a mistake when calling it, the teacher will be there to provide a role model to say the word correctly i.e. the child will pronounce it correctly finally (the role-model principle: 'say what I said'.) 
A role model in language learning, particularly in a Foreign Language, is of critical importance. Whereas the role-model is important, the learning material is the basis of the entire learning in Oral Approval and Situational Language Teaching.

It was the thinking of the proponents of Situational Language Teaching who taught us to believe that the meaning of words or structures is to be induced from the way the form is used in a situation. (Billows, 1996:28) said once upon a time, "If we give the meaning of a new word, either by translation into a home language or by an equivalent in the same language, as soon as we introduce it, we weaken the impression which the word makes on the mind." This meant that explanation was discouraged and the learner was expected to deduce the meaning of a particular structure or vocabulary item from the situation in which it is presented. Extending structures and vocabulary to new situations takes place by generalization.

The learner was expected to apply the language learned in a classroom to situation outside the classroom. This was how child language learning was believed to take place and the same processes were thought to occur in second and foreign language learning, according to practitioners of S L T.

Much as this approach was comparatively more appropriate to teaching a language as a foreign language learner, equally notable are the learning aids which need to be available during the time of teaching to facilitate the process of learning on the part of pupils. The implication is learning a local language by a local teacher is far much easier than learning a language by a teacher who is not a native (SLT)

\subsection{Statement of the problem}

Teaching of any language is a very critical task to a teacher particularly if that teacher is not a native to the language being taught to learners. If the earlier practitioners emphasized on the use of teaching aids, they did so following their own experiences. Most schools have not been doing well in their teaching-learning activities as regards aids thereby producing poor results at examination stages. This is because pupils are unable to acquire language skills due to the fact that pupils do not retain for long or understand what they are taught without teaching aids (Barua, 2006) and as such learning does not encourage participation as it lacks interest or stimulation. This type of learning is not based in a sense on experience nor does it extend their experience but teaching aids have influence on learning. Above all, such learning cannot be permanent. Even so, there is also evidence of low utilization and non-availability of teaching aids in schools.

\subsection{Purpose of the Study}

The purpose of this study was to find out the influence of teaching aids on the learning of language in four selected schools of Mwense District in Luapula Province as the study done by World Bank (2001) noted that teaching and learning materials were critical ingredients in the implementation of curriculum.

\subsection{Research objectives}


1. To assess the influence of teaching aids on language learning.

2. To identify the challenges teachers have in the production of teaching aids.

3. To explore the reasons why teachers do not regularly use aids in teaching English Language.

\subsection{Theoretical Framework}

The study was guided by the Social Interactionist Theory (SIT) which combines ideas from sociology and biology to explain how language is developed with emphasis on the role of environment and context in which the language is learnt. Further, it propounds that language emerges from and is dependent upon social interaction. This theory has its roots in the beliefs of Vygotsky (1978). It focuses on the practice of language rather than grammar which should come later. The theory has a claim that language maturation results from the complex interplay between human faculties (the five senses) and the environment in which the L2 learners are found. Other proponents like Halliday, McIntosh and Stravens (1964) stress the events that take place in the actual situations while Baruah (2006) places a high recommendation on both real and contrived situations. This is where the role of teaching and learning aids finds a place in the imparting of language skills.

\subsection{Significance of the study}

Teaching aids materials have been in existence for a long time, but they are often underutilized. It is expected that following the identification of the hindrances to maximum utilization of teaching aids resources in schools, effort will be made to minimize the effects of the hindrances and promote adequate utilization of the available resources. This grounded study hopes to contribute to the Interactionist Theory (IT), the theory that teaches that language besides being acquired and developed in context, it is interactive in nature. Discoveries from the study will guide teachers, education officers, sponsoring bodies and donors on the purchase of not only printed materials, but also non- print materials for schools and colleges. When the use of teaching aids materials is encouraged, there will definitely be a high demand for the materials and the producers will put in more effort in the production and even come out with more methods of applying them to teaching and learning. Secondly, this study hopes to re-enforce the campaign that encourages teachers to only go to teach their pupils when they have prepared teaching aids. Thirdly, the outcome from the data will help the education section to focus eyes on production of teaching and learning aids. For instance, production of teaching aids in a college of education or university, would be a realistic deliberate policy. This, then will help up-coming teachers to produce (make) aids that are appropriate to the situation or context in which lessons are going to be taught. Finally, the outcome of this research would also help to re-enforce the idea of utilization of local materials as preferred to ready-made learning aids.

\section{Review of Related Literature}

\subsection{History of Teaching Aids}


The concept of Tas is not new and can be traced back to seventeenth century when J. A. Comenius (1592-1670), a Bohemian educator introduced pictures as teaching aids (TAS) in his book Orbis Sensuallum Pictus ("Picture of the Sensual world"). This book was illustrated with 150 drawings of everyday life. In a similar way, Jean Rousseau (1712-1778) and J.H. Pestalozzi (1746-1827) advocated for the use of visual aids and play materials in teaching. More recently, audio-visual aids (AVAS) were also widely used during and after World War II by the armed service. The successful use of pictures and other visual aids in the U.S. armed forces during World War II proved the effectiveness of instructional tools. Today, there are various types of audio- visual materials ranging from film strips, microforms, slides, projected opaque materials, tape recording and flash cards. In the current digital world, Avas have grown exponentially with several multimedia such as educational DVDs, power point, T.v. educational series, You Tube and other online materials.

\subsection{What are Teaching Aids and what are they for?}

Teaching aids are objects, classroom artifacts or equipment that have specially been made to help a teacher to present his lesson to learners in an effective manner. Any device, material or source used by teachers to clarify, describe or explain a topic to pupils better in a classroom, to facilitate effective communication and understanding for children and significantly increase classroom interaction are known as teaching aids. Learning aids on one hand are equipment, tools and devices that aid learners in their learning and development process to be able to meet the expectations of the pupils but not the teachers.. The dictionary of Education (197:622) calls teaching aids material- technical base of university courses has defined them as "natural objects or constructed objects, models, instruments, graphic and other selected materials which can be used as resource, help, encouragement or evidence in the process of learning education."(Anzaku 2011) uses the term audio-visual aids which he says refers to those instructional materials that may be used to convey meaning without complete dependence on verbal symbols or language. The importance of teaching aids materials in the teaching and learning process cannot be over emphasized. Below are some of the roles of teaching aids:

Basing learning in sense experience Stressing the importance of teaching aids, (Ngozi, Samuel and Isaac, 2012) unanimously agree that materials are very important and useful in education because, the normal learner, in so far as the functions of his preceptor mechanisms are concerned, gains understanding in terms of multiple impression recorded through the eye, ear, touch and other series.(Eze, 2013) also states that the human being learns more easily and faster by tas processes than by verbal explanations alone. Further, (Oketunji, 2000) stresses that ta materials when effectively used, they lessen major weakness of verbalism, they humanize and vitalize subject matter, provide interesting approach to new topics and give initial correct impressions. Finally, (Swank, 2011) stressing the effectiveness of ta materials in learning, estimated that about $40 \%$ of our concepts are based upon visual experience, $25 \%$ upon auditory, $17 \%$ on tactile, $15 \%$ upon miscellaneous organic sensation and $3 \%$ upon taste and smell. With the above assertion, it becomes clearer why Tas are important in the teaching and learning processes. This is because they bring the different senses contributed together to get $100 \%$ clarity. 
Extending Experience: (Gopal, 2010) stresses that Ta materials help the teacher to overcome physical difficulties of presenting subject matter. By that he means that with Ta materials, the barrier of communication and distance is broken. The culture and climatic conditions of other countries can be brought into the classroom with the aid of slides, films, filmstrips and projectors. This is important because, according to (Dike, 1993) "Once the phenomenon is visualized, the picture and knowledge becomes very clear and permanent". In agreement to this assertion, a $20^{\text {th }}$ century Chinese philosopher states, "One picture is worth a thousand words".

Encouraging Participation: (Natoli, 2011) once said that Ta materials are rich opportunities for students to develop communication skill while actively engaged in solving meaningful problems. In other words, students certainly like it more and learn better when they are engaged in important and appealing activities. For example, involving students in bulletin board display will enhance their choice of colour and aid their understanding of the concept in question or when they join the teacher in dramatization of an event or a process.

Stimulating Interest: According to (Catherine, 2009), learning takes place effectively when the teacher sets out to provide materials. During the process of learning, the teacher has to provide learning situation to satisfy the natural reaction of the learner and this is through the use of instructional aids. The attention of the learner is caught and his interest is also won and he is ready to learn. Contributing on the role of Tas in stimulating interest, (Hills, 1994) states that a friendly, accepting group climate is important in any learning situations, especially those materials that require students to reveal their ignorance and confront their fellow students. He concludes that when there is a climate of acceptance for learning, then learning is stimulated.

Individualized Instruction: (Lestage, 1959) stressed that teaching aids materials provide a means of individualizing instruction. He said that this is possible through programmed learning and tapes which enable the learner to learn at his pace and also to work on his own. Moreover, according to (Dike, 1993), the machine frees the teacher to work with individual students, since he is not now required to carry out routine drills. Production of resources by students is another way of individualizing instruction.

Serve as a Source of Information: Peterson said, "The child is to think, but he must have information herewith". The teaching aids resources serve, because the information can be gotten from the good use of perceptual instructional materials especially those provided from our locality. When they are used in class, their familiarity gives a background for understanding the information. (Menaught, 2007) also observed that audio- visual materials are very useful teaching, instructional as well as promotional aids. He further stressed that where consistency of presentation is desirable, audio- visual materials are useful. They provide experiences not easily secured in other ways and hence contribute to the depth and variety of learning.

Making Learning Permanent: Teaching aids materials can play a major role of making learning permanent. (Gopal, 2010) notes that audio-visual methods do seem to facilitate the acquisition, the retention and the recall of lessons learned because they evoke the maximum response of the whole organism to the situations in which learning is done. And perceptual materials readily associate themselves with the unique experiential background of each 
individual. As already observed, (Natoli, 2011) repeats to say that audio-visual materials are important in the teaching and learning process because having seen something, most people remember for whatever that thing was, it conjures up an image at a mere mention and can be talked about freely. And (Dike, 1993) explains that students forget because of lack of interest and opportunities to use the knowledge they have gained later on. Audio- visual resources can therefore contribute to the clarity of information presented by allowing students to visualize what is learned hence the Chinese proverb:"What I hear, I forget; WhatI see, I remember and What I do, I know".

Clear emphasis however, is to understand that teaching aids are any device that assist a teacher to transmit to a learner facts, skills, attitudes, knowledge, understanding and appreciation (Kochhar,2013). Teaching aids are very useful but they should be categorized so that they are used conveniently and for the purpose they were made.

\subsection{Types of Teaching Aids}

Having been placed for purpose and convenience, (Kochhar, 2013) has classified these aids into five types: Aids that help pupils through the ear or auditory. In this category we have aids like radio and phonograph or (tape-recorder). Aids through the eye or visual: In this category there are motion pictures, stereotypes, the camera, the chalk board, flannel board, the bulletin board, pictorial materials and representations such as maps, globes, diagrams, etc. The third category is that of aids through the eye and ear (audio-visual). Here we find sound-motion pictures and television. Aids through Activity. This covers school trips, objects, and specimen and module collections and then miscellaneous and in this group we have dramas, booklets magazines and newspapers.

\subsection{The selection and use of Teaching Aids}

(Ellis and Tomlison, 1986) have noted how teachers and administrators of English as a Second Language (ESL) have been subjected to persuasive propaganda designed to convince them of the qualities of a variety of sophisticated and often expensive teaching aids. Many of these aids undoubtedly help to make the teaching of ESL more effective and efficient, but sometimes such aids are bought without a critical appraisal of their limitation and without sufficient awareness of how and when to use them. This lack of forethought can lead to a waste of money and valuable teaching time.

(Straus and Frost, 1999) have identified some factors that should influence the selection of teaching aids and their use and these are the following factors: course content appropriateness, learner characteristics, attitudes and skill levels for pupils, course learning objectives, learning relationships, location of time (synchronous versus asynchronous) and teaching aids usefulness level. (Dick and Raiser, 1996) have however distilled these factors further to three only, namely:

Practicality: This means that a teacher should ask himself a question- Is the teaching aid available, cost efficient, time efficient and understood by a teacher? 
Student Appropriateness: At this stage, the teacher asks himself a question: Is the intended teaching aid appropriate for the developmental and experiential levels of pupils?

Instructional Appropriateness: The teacher at this level is concerned with instructions the teaching aid will provide to pupils and so his questions will be; Is the intended teaching aid appropriate for the planed strategy? Will the teaching aid allow for the presentation of the proposed lesson in an efficient and effective manner? Will the teaching aid facilitate the pupils' attainment of the specific learning objectives? On the other hand, (Dick, Carey and Carey, 2001) specify three major constraints that operate on the selection of teaching aids, each of which may impede the selection process. These are:

(Un) availability of materials: Using existing teaching materials can facilitate the creation of teaching units; however, if no appropriate materials exist then the teacher must produce the materials. This usually leads to a production constraint.

Production Constraint: Production of quality teaching aid can be a costly enterprise, both in time and money. A central question to answer should be; what level of a teaching aid quality is acceptable- that is, in both time and cost efficiency as well as pedagogically effective.

Teacher Facilitation: Most forms of teaching aids involve teacher modeling, demonstration, implementation or more broadly, facilitation. The amount of difficulty of this process of teaching aid facilitation may inhibit a teacher's ability to effectively utilize the particular teaching aid.

In any case, the aid should help the teacher; the teacher should not become the assistant to the teaching aid. The aid must be used only when it can be useful and not merely to justify why it was bought or made. The aid must be chosen because it can help a particular teaching situation instead of a particular teaching situation being chosen because it can be helped by a particular teaching aid. (Baruah, 2006) says, "Contrived situations would be more advantageous with teaching aids than actual physical situations." Teaching aids can dispel the monotony of practice work by creating variety. The use of teaching aids to teach word-meaning is obvious. The meanings of some words can be taught only with the help of visual aids. Audio - aids like the radio and the tape - recorder can be used by the teacher to improve his own command of the language and wherever practicable, they can also be used in the teaching of word sounds and rhymes.

(Muzumara, 2001) has further noted that teaching aids help pupils to improve all the four basic skills in reading, writing, speaking and listening. As noted earlier, when a reader is used in oral/listening lesson, pronunciation of words will be given correctly following the model in the cassette recorder and thus reinforcing what the teacher teaches. Teachers can use TAs to ensure that concepts, theories and principles are understood and appreciated. When learners appreciate their teacher's lessons, their morale is boosted and skills are readily employed into their class activities, thus aids can relieve anxieties, fears or boredom.

\subsection{Why do some teachers shy away from using Teaching aids?}


There are many reasons why some teachers avoid using teaching aids in their lessons in class rooms. There are various reasons teachers why a teacher may shy away from using teaching aids as some of them may be unfamiliar to a teacher who may want to use them. Some teachers think teaching aids are difficult to make and they cannot find someone to make these materials for them and so the plan to use teaching aids in their lesson is either postponed to next time or abandoned all together. Scarce materials for making teaching aids as materials for making teaching aids are not easy to find especially in schools in the country side. But (Muzumara, 2001) and (Muzia, 2017) say that teaching aids do not need to be complicated. Simple teaching aid which will serve the purpose will be more desirable. Some teaching aids are expensive and (Kelly, 1999) attributes to the fact that the cost of teaching aids is so much that some schools may not afford to buy these. Cassette recorders, radios and language laboratory equipment are some of the expensive learning materials but very necessary in language learning and teaching.

\subsection{Some Basic Teaching aids in English Language Teaching}

There are various types of aids that can help a teacher to teach effectively. Some of the basic teaching aids with multiple uses in English as a Second Language Lessons are:

The Chalkboard: This is a traditional symbol of the classroom; and if properly used, the teacher can still get a lot out of this dependable aid. Ellis and (Tomlison, 1986) have called this aid the simplest manufactured aid and potentially the most useful aid. It is the most permanent in the ESL classrooms. The chalkboard can be used for activities in the teaching of Language such as developing Aural-Oral Skills, for situational teaching, for developing reading and writing skills, for making the meaning of words clear by using simple sketches, besides writing sentences to put the words in self-defining context and the teacher can also put up the comprehension questions on the board and engage pupils to find out the answers from the reading passage. The chalkboard can be used for teaching various tasks such as how to teach composition. (Free and guided) spellings, dictation and writing letters, and so on and also for teaching grammar.

The teaching and learning aids the teacher can use are:

Charts and Tables: Large charts and tables can be used for development of all the four skills as well as for imparting the essential knowledge of structures and vocabulary. Pupils can be asked to read sentences from charts and tables and write them. In the early years the pupils can read sentences and rhymes from charts. They are helpful in choral recitations of rhymes and jingles from charts.

Flash Cards: Cards containing letters, words, phrases, sentences etc are a very useful and inexpensive aid in teaching English. The letters in the cards should be sufficiently large so that when the teacher puts up a card the pupils on the far end should read without difficulty. These cards are used for a variety of purposes. For example they are used for "look and say "method, sentence making and word-making etc. 
The Flannel Board: This consists of a piece of cloth on which on which can be stuck cut-out figures which can be bought or be cut out from magazines, posters, etc. The figures can be stuck on the cloth so that they can represent a context of reality and they can be moved around so as to serve as a visual accompaniment to a continuous story.

Flip Charts: A flip chart consists of a number of pieces of card. On each card there is a drawing and when put together in the correct sequence the cards tell a continuous story. The cards are of the same size and are attached to each other by a piece of string which fits through holes at the top the cards. Thus the teacher is able initially to show just the first card to the class; then he can flip over the first card and the second card becomes the only visible one. In this way the teacher is able to provide a visual reinforcement of a continuous story but is also able to focus attention on one aspect of the narrative at a time.

Wall Pictures: Large pictures showing, for example, a street scene, a market place, a playing field, etc, can be very effective for oral practice and for writing connected sentences. (Baruah, 2012: 300) notes that a series of such pictures can also be used to narrate a story in the manner of the popular comics. Wall Pictures are available in the market, but a teacher can easily make his or her own. The picture needs not to be perfect. Figure can be traced from magazines or drawing books. Even cut-outs can be pasted on a large sheet of paper to make an interesting wall picture. Use of a variety of colours will make pictures attractive.

Apart from the basic teaching aids discussed above, there are other more expensive and sophisticated aids. Some of them are: Radio, Tape recorder, Slide projector, Overhead projector, Film projector, Television, Language Laboratory, Video tape/Cassette recorder, Computer and so on. Even when Tas are available, the teacher should ensure that the teaching aid is going to work as effectively and efficiently as possible according to the purpose they were made for.

\section{Research Methodology}

\subsection{Research Design}

The study adopted a descriptive survey design using both quantitative and qualitative methods as this design seeks to obtain information that describes existing phenomena by asking individuals about their perceptions, attitudes, behaviours and what guided the choice of the design characteristics was, first and foremost, the nature of information to be captured and then also, the data most suitable for the study, Garg and Kothani (2014).

\subsection{Research sites}

This study was under taken from the five schools in Mwense District namely Kipena Primary, Lukusa Primary, Mulonge Primary, Lubinda Primary and Kakomba Primary School. These schools lie between three to fifteen kilometers from the DEBS office, the furthest being Kipena about 15 kilometers from Mwense District Administrative center. The research sites are basically rural and people rely on farming and fishing for their livelihoods. 


\subsection{Population, Sample and Sapling Procedure}

The population for research comprised of Head teachers, Senior teachers, teachers, pupils and District Education Standards Officer. The total sample size consisted of 121 participants, that is, 1 District Education Standards Officer, 5 Head teachers, 5 Senior teachers, 10 teachers and 100 pupils. Sampling procedure is a process of selecting a number of individuals or objects from a population such that the selected group contains elements representative of the characteristics found in the entire population, Agesa (2012) and the respondents were selected through purposive and simple random sampling methods.

\subsection{Data Analysis}

In this study, data was analysed qualitatively as the semi structured interviews and questionnaires were used as data collection instruments. Thematic approach was used, where data analysis started with the categorization of themes from the semi structured interviews and questionnaires (Smith, 2013).Charts and graphs were used to analyse data. The data gathered was analysed according to the themes of the study, the order of the research objectives and questions. The research collected data through in-depth interviews, classroom observations and questionnaires. Qualitative data collected collected was analysed using thematic analysis while quantitative data collected was analysed through the use of Microsoft Excel and Statistical Package for Social Sciences (SPSS) for generation of tables, graphs, pie charts, percentages and frequencies.

\subsection{Ethical Considerations}

The researcher got permission from Debs and school authorities and consents, assents from respondents who were involved in the research. The research topic was strategically selected to ensure that there was no harm whatsoever to the research respondents and the researcher was fully conscious of the need to abide by the ethical rule of respecting the privacy of individuals taking part in the research. In the same way, all the respondents of the research were to remain unidentified to the public as all their valuable views, opinions as well as their identities will forever remain hidden.

\section{Research Findings and Discussions}

The study investigated the influence of teaching and learning aids on language learning in selected schools and the collection of research data was guided by the following questions:

(a) What is the influence of teaching aids on language learning?

(b) What challenges do teachers face in the production of teaching aids?

(c) Why do teachers regularly teach English Language without the use of aids?

\subsection{Influence of teaching and learning aids on learning}

When asked on the extent teaching aids influenced learning, $68 \%$ of the respondents answered that the teaching aids influenced learning above average while $32 \%$ said they influence learning 
at average level and this is illustrated in figure 1 below. Teaching and learning process derives a lot on human senses. This means that when a teacher uses a teaching aid, a good number of senses will be employed; for example, hearing, sight and touch, (Ngozi, 2012). The influence of teaching aids was above average and this finding was in tandem with (Chilembo, Kilele and Nyendwa, 2020), (Sappiah, 2017) and (Romiszowski, 2018) who keenly observed that a lesson accompanied by a teaching aid and presented by a versatile teacher should have much more influence than the one without a teaching aid. These findings were also in line with the findings of (Ngozi, 2012) who noted that teaching aids appeal to all senses, teaching aids engage pupils causing a lesson to be more interactive rather than it be a monologue of a lecture method.

\section{Figure 1. How much influence do teaching aids have on the learning of a language?}

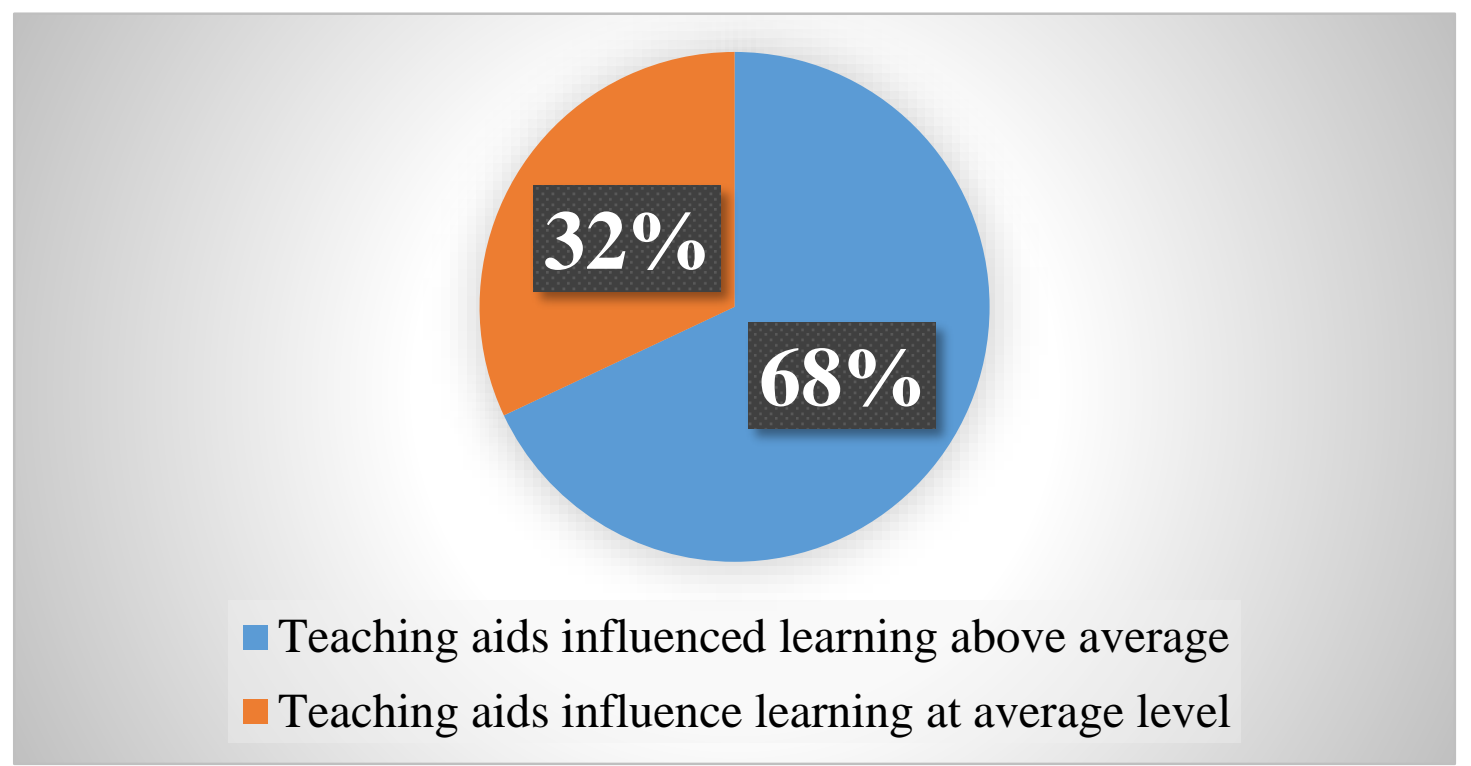

Source: Research findings 2020

\subsection{Teachers use of teaching and learning aids}

Teachers as they are known are key drivers of education. They understand better mechanisms they can put in place to make the pupils' learning process effective. This is the reason why when the teacher uses a teaching aid the lesson is quite satisfying even to the teachers themselves. In figure 2 below, the study found that $23 \%$ of respondents acknowledged that they rarely used teaching aids while $2 \%$ used aids in every lesson and the majority $75 \%$ were not sure of when and how often they used aids. However, two things stand out. Use of teaching aids needs to be part and parcel of every lesson, not just at sporadic periods. Secondly, the $23 \%$ that responded, 'it depends' was a lukewarm cohort that needed quick attention to capacitate them so that they too, should be satisfied with the use of teaching. (Hills, 1994) observed that when there is a climate of acceptance for learning, then learning is stimulated. Furthermore, Dick and Raiser (1996) have noted that most forms of teaching aids involve teacher modeling, demonstration and implementation broadly known as facilitation. Most teachers in schools 
have challenges in delivering effectively to their classes because they go to class without any teaching aid.

\section{Figure 2. How often teachers use teaching aids}

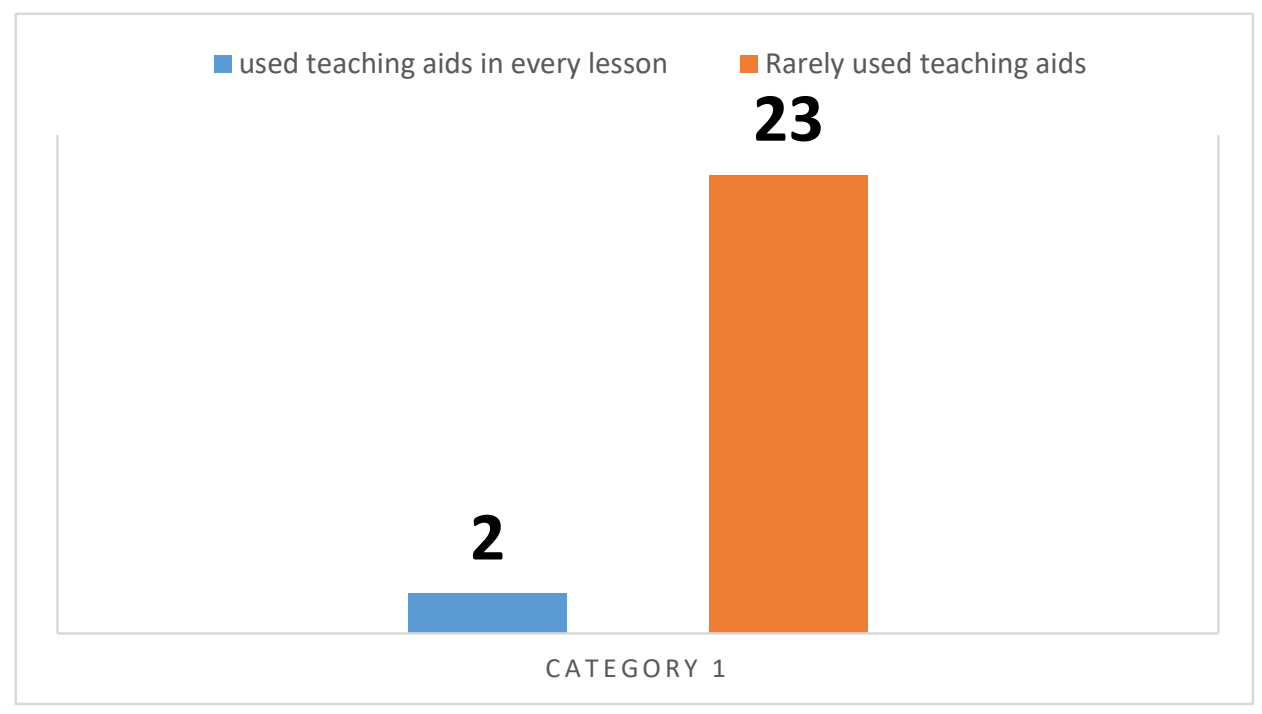

Source: Research findings 2020

Most teachers do not use teaching aids when teaching their lessons. Since most teachers do not use teaching aids in teaching, pupils in most lessons are passive participants because the interactive parts are 'stolen' by the teacher; who alone In most schools, classroom walls are rarely dressed, even in those schools where doors and windows close effectively. Teachers rarely make or produce their own teaching aids. Pupils' level of achievement is stagnated due to limited participation, lack of creativity and curiosity.

\subsection{Improvisation in schools}

Teaching aid materials if not well stored, cannot last for a long time. Because of this, many schools do not have ready- made teaching aids that were distributed by the government in the 70 s up to 80 s. There were, also wonderfully locally made teaching aids made by teachers who trained in the 70s and 80s. These materials were well stored and helped a lot in the learning process of the pupils. With passage of time, the teaching aids got worn out and were not replaced because perhaps there is no one who is keenly interested in making teaching aids to help pupils in their learning process. Figure 3 below shows that only $88 \%$ of the respondents did not improvise and only $18 \%$ improvised teaching aids in schools. However, (Mwanza, 2020) advised that a committed teacher to his or her pupils should always made a personal effort to see to it that his or her children were provided with the suitable materials in every lesson.

Secondly, school administrators who are keen in the learning process of the pupils will always think of the learning materials and procure them. Mwanza (ibid) attests however, that there are schools that do not have any teaching aid in school yet children go into class to learn every 
day. He wonders what pupils can learn in class without teaching aids. He levels the blame on school managers who allow any teaching unaccompanied by a teaching aid.

\section{Figure 3: Improvisation of teaching aids}

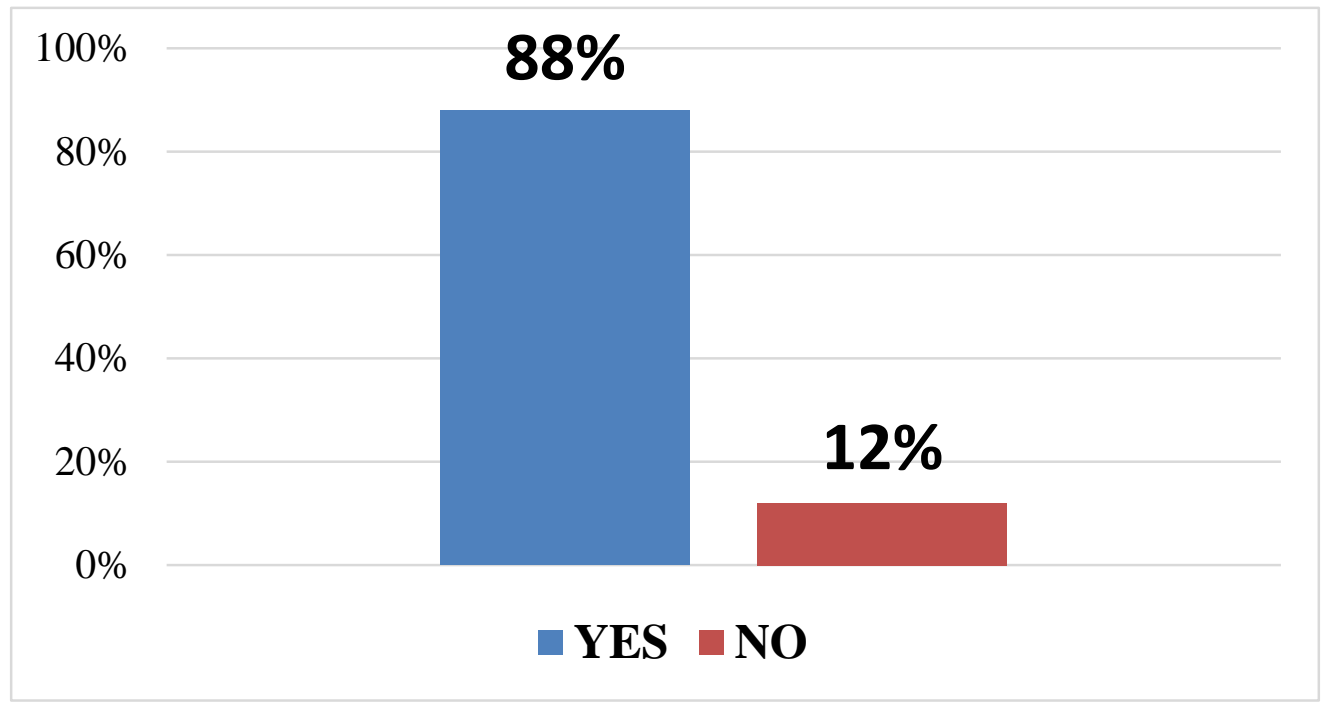

Source: Research findings 2020

Figure 4: Sourcing of teaching aids

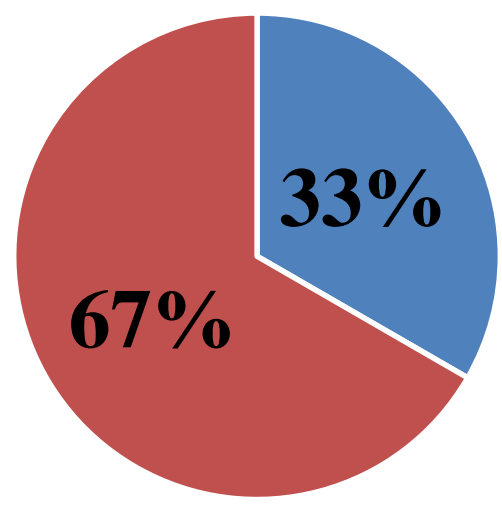

- The teaching aids were sourced by other means

- School bought the teaching aids

As illustrated in Figure 4 above, $67 \%$ of the respondents acknowledged that teaching aids were sourced by other means while $33 \%$ said that the school bought the teaching aids. This is a clear indication that many teachers today lack the initiative that teachers had in the $70 \mathrm{~s}$ and $80 \mathrm{~s}$ Although there were ready- made teaching aids that were distributed by the government, teachers made their own from carton boxes, manila paper but many made out of local materials. While at colleges, most of the assignments they did involve making artifacts that would be used for teaching of every kind. 
Most colleges these days do not teach their students how to make teaching aids. The lecturers themselves are not able to manipulate a pencil and draw nor are they able to carve or weave. The result of a poor lecturer is a poor student teacher. Student teachers today are even incapable of chalk board management because hand writing is out of syllabus in colleges. Assignments that most lecturers give are bookish rather than practical. Production of teaching aids is not a standalone task. It goes together with lesson preparation, lesson delivery and use of teaching aids in the delivered lesson. A keen head teacher will monitor each stage of the activity himself or herself, may delegate to the deputy or to the Senior teacher. But if the manager is aloof as (Kunkhuli, 2014) would say, the pupils will suffer because that teacher will not be delivering according to the acceptable standards.

\subsection{Lack of C.P.D Meetings in schools}

Continuing Professional Development (CPD) is the holistic commitment of professionals towards the enhancement of personal skills and proficiency throughout their careers. The term CPD is used to describe the learning activities professionals engage in to become conscious and pro- active rather than passive and reactive. CPD combines different methodologies to learning such as training workshops, conference and events, e- learning programmes, best practices techniques and ideas sharing- all focused for an individual to improve and have effective professional development. (Daka and Ngoma, 2004) advised that through CPD meetings senior teachers were able to assess the ability of every individual member of the school. "It is through these meetings that many teachers whose background was not effective are given local workshops to capacity build those teachers"(Daka and Ngoma, ibid).

Engaging in CPD ensures that both academic and practical qualifications do not become out dated or obsolete; allowing individuals to continually 'up skill' or 're- skill' themselves regardless of occupation, age or educational level, (Jere,2006). True to this fact, CPD meetings enables individuals to adapt positively to changes in work requirements. Planning CPD helps to become more efficient with time, and recording CPD properly provides evidence of professional development. It shows clear commitment to self-development and professionalism. It provides an opportunity for an individual teacher to identify knowledge gaps and resolve these gaps in a recognizable approach to improvement.

Schools where CPD meetings are active benefit their schools through recognition and increased brand perception. In schools CPDs encourage and promote a healthy learning culture for the individual department, leading to more fulfilled workforce and retaining valuable staff. Among other activities for CPD meetings (Daka, 2004) highlights various presentation of English Language components like prose summary, comprehension, narrative composition, production of teaching aids and effective use of teaching aids. Thus if CPD meetings are conducted in the school, teachers will be acquainted with many key issues and skills that they need to have in order to handle pupils even those that sit for final examinations confidently.

\section{Conclusion}


Teaching aids are an integral part of teaching and learning process. This symbiotic activity can never be complete without them as they form the situation or context of pupils' learning environment. It is clear that teaching aids are important tools for teaching as they help a teacher to present a lesson effectively and pupils learn and retain the concepts better and longer. The use of teaching aids improves pupils' critical and analytical thinking. Many teachers however, teach without teaching aids because these materials are not available in school and teachers cannot produce their own. In order to help teachers produce their own teaching, colleges and universities should teach their students how to make local teaching aids which are cheaper but valuable. In school, CPD meetings should be intensified in order to build the capacity of those in need. Notwithstanding the fact that methodology hastens teachers to use teaching aids, there should be an incentive for teachers who make and use teaching aids very well. It is important for teachers of English to take their lessons with pupils from the context, for example the teaching of polite requests can be done at the market or at the shops in order to deal with reality rather than abstract.

\section{Recommendations}

The findings of the research study were based on the conclusions and were as follows:

1. Teaching without a teaching aid is cheating and therefore, teachers should accompany their teaching with a teaching aid.

2. Since ready- made teaching aids are expensive, schools should emphasize on making teaching aids from local resources. The production of teaching aids should be drafted as a compulsory course at all teaching Colleges and Universities.

3. CPD meetings should be an on-going exercise so that teachers should have refresher course through them and should have emphasis on improvisation.

4. There should be a follow-up comparative research study to be conducted on the localized type of teaching aids and the exotic ones.

\section{References}

1) Abagi, J.O et al (1989) Language Policy and Science Instruction in Kenyan Primary Schools: Comparative Educational Review; vol. 33: Nairobi.

2) Akers, R. (2011) Instructional Materials; New York: Pearson.

3) Alwright, R. L.(2011) Why do we Want Teaching Aids for? Currents in Language; Oxford: Oxford University Press.

4) Anzaku, F. (2011) Library Experts Speak on Audio- Visual Material. A paper presented at the UNESCO World Day for Audio- Visual Heritage. Lafia.

5) Arthur, J. et al (2012) Research Methods and Methodologies in Education, London:

6) Baruah, T. C. (2012) The English Teacher's Handbook; New Delhi: Sterling.

7) Berman, J (2013) Teaching Aids In English Language; Cambridge: Cambridge University Press.

8) Brown, D.(2012).Teaching by Principles: An Interactive Approach to Language pedagogy; San Francisco: Longman. 
9) Catherine, V. (2011) Interactive Teaming; New York: Prentice Hall.

10) Chaturika and Rajapaksha Randima, P. L. N (2015) The use of Teaching Aidsin the Teaching and Learning Process. International Journal of Multi Disciplinary Studies vol.2 Issue 1, 2015.

11) Cohen, L (2012) Teaching Methods in the Foreign Language; Pennsylvania: University of Pennsylvania

12) Creswell, J. W. (1998) Qualitative Inquiry and Research Design; London: Sage.

13) Daka, J.F and Ngoma, T.J.V. (2004) Re-Equipping For Success: A paper Presented at A District Workshop for Teachers of English Language, Katete.

14) Dike, V.W. (2013) Library Resources in Education; Enugu: ABIC

15) Ellis, R. and Tomlison, B (1980) Teaching Secondary English; Essex: Longman.

16) Eze, E. U. (2015) Effect of Instructional Materials on the Academic Performance of Junior Secondary School Students in Social Studies. PGDE Thesis. Imo State University: Unpublished.

17) Gopal, V. P. (2011) Importance of Audio- Visual in Teaching Methodology; Mahourastra: New Delhi.

18) Hamid, M (2011) Socio- Economic Characteristics and English Language; Bangladesh

19) Kachaso, L (1988) Language Effect on Pupils' Performance in Mathematics in Standard 7 MAE Dissertation, Zomba. Unpublished.

20) Kamocha, H. (2011) Factors Contributing to Low Participation in Literacy Programmes, Lusaka University of Zambia- unpublished

21) Katherine, M.(2012) Audio- Visual Materials: Collection Development Policy; Rod Library University: Iowa

22) Kasonde-Ng'andu,S.(2013)Writing Research Proposal in Education Research; Lusaka: University of Zambia Press.

23) Kelly M.J (1999) The Origins and Development of Education in Zambia: From Pre-Colonial Times to1996; Lusaka: Image

24) Kochhar, S.K (1985) Methods and Techniques of Teaching; New Delhi: Sterling.

25) Kumar, G. C (2013) An Introduction to Linguistics and Grammar; New York: Oxford.

26) Kumar, G. C (2013) The of Study Grammar; New York: Saddle River.

27) Kunkhuli, S. W.M (2014) Perceptions of Principals and Climates of Zambia's 'Effective' Schools; Phd Thesis, Xlibris: London.

28) Lewis, L (2014) The Development of Grammar; London: Cambridge University

29) Lestage, A (2019) The Use of Audio- Visual Aids in education; UNESCO: Mexico City

30) Lonigan, C (2012). Developing Early Literacy Report; California: National Institute of Literacy.

31) Mangal, S. K.(2014) Essentials of Educational Technology; New Delhi: PHI Learning.

32) Muijs, D and Reynolds, D (2011) Effective Teaching: Evidence and Practice; London: Sage. 
33) Muzumara, P. M. (2001) Teacher's Competences for Improved Teaching and Learning; Lusaka: Bhuta

34) Mwanakatwe, J M (1968) Growth of Education Zambia since Independence; Lusaka: Oxford.

35) Natoli, C. (2011) The Audio - Visual materials in Teaching and Learning. wwwhelium.com/channels/224.earlyearly-childhood

36) Ngozi, B et al (2012) Motivating Use of Audio- Visual in a Nigeria Technological University Library; Journal of Education and Social Research vol2 (1) Jan.

37) Nilson, L. (2016) Teaching at Its Best: A Research- Based Resource for College Instructions; London: Routledge.

38) Ojowu, O.E. (2014) the Impact of Audio - Visual Aids Resources on Teaching and Learning in Selected Private School in Makurdi. International journal of Research in Humanities. Lagos

39) Prostano and Prostano (2012) The School Library ;Medis Centre: Chicago

40) Richards, J. (2012) Beyond Training: Creating Effective Language Lessons; Cambridge: Cambridge University Press.

41) Richards, J C and Rodgers, T S (2001) Approaches and Methods in Language Teaching; Cambridge: Cambridge.

42) Rivers, W. (1968)Teaching Foreign Language Skills; London: University of Chicago.

43) Romiszowsk, J (2018) The Selection and Use of Teaching Aids: London: Routledge

44) Sinkamba, D C (2010) Reading Levels in English for Grade 4 Pupils in Selected Community Schools in Chinsali District; Lusaka ZOU unpublished.

45) Snelson, P D (1974) Education Development in Northern Rhodesia - 1853 - 1945, Lusaka: NEDCOZ

46) Stevenson, K.R (2007) Language and Environment; Washington: CUP.

47) Suppiah, N.et al (2017) The Implication of using Teaching Aids in the Teaching of the Science and Technology Components in Malaysian Preschool. I International Journal of Academic Research in Business and Social Sciences: 2017, vol.7 no.11 ISSN2222-6990.

48) Swank R. C. (2011) the Education Function of a University Library. http://www.idealsIllinos.edu/bitestream/handle/2142/5455/librarytrend.

49) Yasim, I.M.M. et al (2016) The use of Teaching Aids in the Teaching \& Learning of Arabic Language Vocabulary: Creative Education: Scientific Research Publishing

\section{Author' Biography}

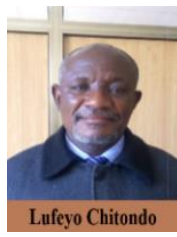

Lufeyo Chitondo specializes in Language Education and is currently lecturing at Rockview University in the Department of Literature and Language.

Citations: Lufeyo Chitondo. "Influence of teaching and learning aids on language learning in four selected schools of Mwense District in Luapula Province, Zambia." 